\title{
Identification of Minor Secondary Metabolites from the Latex of Croton lechleri (Muell-Arg) and Evaluation of Their Antioxidant Activity
}

\section{Simona De Marino ${ }^{1}$, Fulvio Gala ${ }^{1}$, Franco Zollo ${ }^{1}$, Sara Vitalini ${ }^{2}$, Gelsomina Fico ${ }^{2}$, Francesco} Visioli $^{3}$ and Maria Iorizzi ${ }^{4, *}$

${ }^{1}$ Dipartimento di Chimica delle Sostanze Naturali, Università degli Studi di Napoli "Federico II",Via D. Montesano 49, I-80131 Napoli, Italy; E-mail: sidemari@unina.it, fgala@unina.it, fzollo@unina.it

2 Dipartimento di Biologia, Università degli Studi di Milano, Via Celoria 26, I-20133 Milano, Italy; Email: gelsomina.fico@unimi.it, sara.vitalini@unimi.it

${ }^{3}$ UMR7079,UPMC Univ Paris 06, Paris, France; E-mail: francesco.visioli@snv.jussieu.fr

${ }^{4}$ Dipartimento di Scienze e Tecnologie per l'Ambiente e il Territorio, Università degli Studi del Molise, Contrada Fonte Lappone, I-86090 Pesche (Isernia), Italy

* Author to whom correspondence should be addressed; E-mail: iorizzi@unimol.it; Tel.: +39 0874 404100; Fax: +390874 404123.

Received: 6 May 2008 / Accepted: 29 May 2008 / Published: 1 June 2008

Abstract: Dragon's blood (Sangre de drago), a viscous red sap derived from Croton lechleri Muell-Arg (Euphorbiaceae), is extensively used by indigenous cultures of the Amazonian basin for its wound healing properties. The aim of this study was to identify the minor secondary metabolites and test the antioxidant activity of this sustance. A bioguided fractionation of the $n$-hexane, chloroform, $n$-butanol, and aqueous extracts led to the isolation of 15 compounds: three megastigmanes, four flavan-3-ols, three phenylpropanoids, three lignans, a clerodane, and the alkaloid taspine. In addition to these known molecules, six compounds were isolated and identified for the first time in the latex: blumenol B, blumenol C, 4,5-dihydroblumenol A, erythro-guaiacyl-glyceryl- $\beta-O-4$ 'dihydroconiferyl ether, 2-[4-(3-hydroxypropyl)-2-methoxyphenoxy]-propane-1,3-diol and floribundic acid glucoside. Combinations of spectroscopic methods $\left({ }^{1} \mathrm{H}-,{ }^{13} \mathrm{C}-\mathrm{NMR}\right.$ and 2D-NMR experiments), ESI-MS, and literature comparisons were used for compound 
identification. In vitro antioxidant activities were assessed by DPPH, total antioxidant capacity and lipid peroxidation assays. Flavan-3-ols derivatives (as major phenolic compounds in the latex) exhibited the highest antioxidant activity.

Keywords: Croton lechleri; Sangre de drago; Euphorbiaceae; Latex; Secondary metabolites; Antioxidant activity

\section{Introduction}

Croton lechleri (Muell-Arg) (Euphorbiaceae), is a tree which grows in the low mountainous areas of the Peruvian Andean regions, as well as in Colombia, Ecuador and Bolivia and it is known for its therapeutic properties. The bark, when slashed, releases a reddish or yellowish latex called "sangre de drago" or "sangre de grado" or "dragon's blood". The blood-red latex or sap is a common household remedy in Peru and in other Latin American countries, where indigenous tribes use it internally and externally to stop bleeding, help heal wounds, and treat intestinal ailments [1]. The results of in vitro and in vivo studies support the use the viscous latex, which exhibits antioxidant [2,3] antiviral [4] and anti-inflammatory [5] activities, in addition to being efficacious in the treatment of different types of diarrhoea, including cholera [6]. The oral administration of a compound, termed SP-303, isolated from the bark latex by Ubillas et al. [4], leads to positive results in the treatment of traveller's diarrhoeas [7] and diarrhoeal episodes in AIDS patients [8]. Recently a novel extract, named SB-300, was formulated and made commercially available [9]. When applied to the skin for treating abrasions and blisters, the red sap forms a seal, protecting the lesion $[10,11]$. It is applied topically to reduce the symptoms of insect bites with a reduction of swelling and redness $[10,12]$. The sap has been used in the treatment of several types of tumors [13-15]. Since free radicals may participate in the early stages of carcinogenesis, recently antioxidant activity was evaluated against the oxidative damages induced by apomorfine in Saccaromices cerevisiae [16].

The chemical constituents of several species of genus Croton have been extensively investigated. The characteristic secondary metabolites are proanthocyanidins, which account for up to $90 \%$ of dry weight and many polyphenolic components such as catechin, epicatechin, gallocatechin, epigallocatechin and dimeric procyanidins B-1 and B-4 [17]. Several minor constituents were also identified: clerodane diterpenoids such as korberin A and B [18], bincatriol, crolechinol, crolechinic acid [19] and the dihydrobenzofuran lignan 3',4-O-dimethylcedrusin [5]. Work on C. lechleri led to the isolation of a benzylisoquinoline-like alkaloid taspine in the sap [1,11] and thaliporphine and glaucine in the leaves [14]. Taspine and the lignan 3',4-O-dimethylcedrusin are thought to be responsible for the wound healing actions of sangre de drago, because of their stimulatory actions on wound repair $[2,11,15]$.

\section{Results and Discussion}

In the present study we have identified minor chemical components of Croton sap to support its medicinal exploitation. The raw material was subjected to a bio-guided fractionation process to isolate 
and identify the main antioxidant non-volatile components. Over the past few years, considerable effort has been devoted to optimizing the extraction of phenolic compounds from herbs and plants. We show here that the crude extracts of $C$. lechleri sap contains a great variety of phenolic components, along with several compounds of very different chemical structures. Our systematic study established a correlation between the chemical composition of the phenolic fractions and their antioxidant activities. Chromatographic separation by Sephadex ${ }^{\circledR}$ LH-20 was followed by DCCC (droplet counter-current chromatography), which is a key step in the purification of complex mixtures of natural compounds. The final purification by HPLC led to the identification of blumenol B (1), blumenol C (2) [20], 4,5dihydroblumenol A (3) [21], (-)-epicatechin (7), (+)-catechin (8), (-)-epigallocatechin (9) and (+)gallocatechin (10) [17], 3',4-O-dimethylcedrusin (4) [5], ( \pm ) erythro-guaiacyl-glycerol- $\beta-O-4$ 'dihydroconiferyl ether (5) [22], 2-[4-(3-hydroxypropyl)-2-methoxyphenoxy]-propane-1,3-diol (6) [23], floribundic acid glucoside (14) [24] and taspine (15) [5].

Figure 1. Secondary metabolites isolated from the latex of Croton lechleri (Muell-Arg).<smiles>[R]C1=CC(=O)CC(C)(C)[C@@]1(C)CCC(C)O</smiles>

$1 \mathrm{R}=\mathrm{OH}$ Blumenol B

$2 \mathrm{R}=\mathrm{H}$ Blumenol $\mathrm{C}$<smiles>CC(O)/C=C/C1(O)C(C)CC(=O)CC1(C)C</smiles>

3 4,5-Dihydroblumenol A<smiles>COc1ccc([C@@H]2Oc3c(OC)cc(CCCO)cc3C2CO)cc1OC</smiles>

4 3',4-O-Dimethylcedrusin<smiles>COc1cc(CCCCO)ccc1OC(CO)C(=O)OCCO</smiles>

6

2-[4-(3-Hydroxypropyl)-2-methoxyphenoxy]-propane-1,3-diol

\section{5}<smiles>[R]C1Cc2c(O)cc(O)cc2O[C@H]1c1ccc(O)c(O)c1</smiles>

$7 \mathrm{R}=\cdots \mathrm{OH}$ Epicatechin

$8 \mathrm{R}=-\mathrm{OH}$ Catechin

$( \pm)$ erythro-Guaiacyl-glycerol-

-O-4'-dihydroconiferyl ether<smiles>[R]C1Cc2c(O)cc(O)cc2O[C@H]1c1cc(O)c(O)c(O)c1</smiles>

$9 \mathrm{R}=\cdots \cdots \cdots \mathrm{OH}$ Epigallocatechin $10 \mathrm{R}=-\mathrm{OH}$ Gallocatechin<smiles>COc1cc(/C=C/CO)cc(OC)c1OC</smiles>

11

trans-3,4,5-Trimethoxy-cinnamic alcohol<smiles>[R]c1cc(CCCO)cc(OC)c1OC</smiles>

$12 \mathrm{R}=\mathrm{H}$

3-(3,4,5-Trimethoxyphenyl)-1-propanol

$13 \mathrm{R}=\mathrm{OCH}_{3}$

3-(3,4-Dimethoxyphenyl)-1-propanol 
Figure 1. Cont.

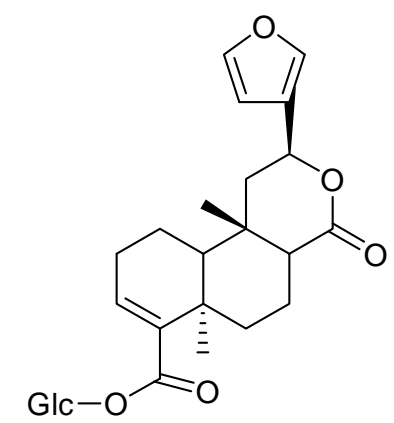

14 Floribundic acid glucoside<smiles>COc1ccc2c(=O)oc3c(OC)cc(CCN(C)C)c4c(=O)oc1c2c34</smiles>

15 Taspine

Among the 15 secondary products isolated in the present study (Figure 1), the nor-isoprenoid derivatives blumenol B (1), blumenol C (2), 4,5-dihydroblumenol A (3), the lignane derivatives 5 and $\mathbf{6}$ and the clerodane glucoside $\mathbf{1 4}$ have not previously been isolated from the genus Croton. Their structures were confirmed by comparison of the ${ }^{1} \mathrm{H}-$ and ${ }^{13} \mathrm{C}-\mathrm{NMR}$ and mass spectra data with published values.

Molecules with megastigmane skeletons, albeit having been described, are relatively rare in the Euphorbiaceae family. The existence of proanthocyanidins seems to be the characteristic of $C$. lechleri, however we did not identify any oligomeric components, while the most abundant compounds isolated were (-)-epicatechin (7), (+)-catechin (8), (-)-epigallocatechin (9) and (+)gallocatechin (10), previously found in several Croton saps.

The distribution of phenolic flavan-3-ols between the $n$-butanol and the $\mathrm{CHCl}_{3}$ extracts revealed some interesting features. The principal component in the $n$-butanol extract was gallocatechin (10; $11.8 \mathrm{mg}$ ), followed by epigallocatechin $(\mathbf{9} ; 5.2 \mathrm{mg})$ and epicatechin $(7 ; 3.0 \mathrm{mg})$. Epicatechin has also been isolated, in lower concentrations, as a component of the $\mathrm{CHCl}_{3}$ extract, along with catechin (8; $4.0 \mathrm{mg}$ ); reflecting these compositions, the highest antioxidant activity was detected in the $n$-butanol extract, compared to the $\mathrm{CHCl}_{3}$ extract. In the chloroformic extract, flavan-3-ol components were accompanied by several other phenolic constituents.

Lignans were reported in the latex of various Croton sp. [5]. Along with the known 3',4-Odimethylcedrusin (4), two rare components were identified, for the first time, in the title species: 1-(4hydroxy-3-methoxyphenyl)-2-[4-(3-hydroxypropyl)-2-methoxyphenoxy]-propane-1,3-diol (5) and 2[4-(3-hydroxypropyl)-2-methoxyphenoxy]-propane-1,3-diol. (6).

Compound 5, also termed erythro-guaiacyl-glycerol- $\beta-O-4$ '-dihydroconiferyl ether, was identified on the basis of its spectroscopic data. The EI-MS spectrum showed a molecular ion peak at $\mathrm{m} / \mathrm{z} 378$ $[\mathrm{M}]^{+}$which is consistent with a molecular formula of $\mathrm{C}_{20} \mathrm{H}_{26} \mathrm{O}_{7}$.

The ${ }^{1} \mathrm{H}-\mathrm{NMR}$ (Table 1) and ${ }^{1} \mathrm{H}-{ }^{1} \mathrm{H}$ COSY spectra revealed four spin systems. Six aromatic protons were attributed to two aromatic rings: the first one was 1,3,4-trisubstituted, with a narrow doublet at $\delta$ $7.02(J=1.6 \mathrm{~Hz})$, a doublet at $\delta 6.77(J=8.1 \mathrm{~Hz})$ and at $\delta 6.87(\mathrm{dd}, J=1.6,8.1 \mathrm{~Hz})$. The second aromatic system was 1',3',4'-trisubstituted and characterized by signals at $\delta 6.98(\mathrm{~d}, J=8.1 \mathrm{~Hz}), \delta$ $6.73(\mathrm{dd}, J=8.1,1.7 \mathrm{~Hz})$ and $\delta 6.87(\mathrm{~d}, J=1.7 \mathrm{~Hz})$. The COSY spectrum also indicated the presence of a glycerol-type moiety from C-7 to C-9 $[\delta 4.88(\mathrm{~d}, J=4.7 \mathrm{~Hz}), \delta 4.20(\mathrm{ddd}, J=4.7,3.8,3.0 \mathrm{~Hz})$ and $\delta$ 
$3.47(\mathrm{dd}, J=12.1,3.8 \mathrm{~Hz}), \delta 3.72(\mathrm{dd}, J=12.1,3.0 \mathrm{~Hz})]$. In accordance with the erythro relative configuration, a coupling constant value of $4.7 \mathrm{~Hz}$ between $\mathrm{H}-7$ and H-8, was observed [25, 26].

Table 1. ${ }^{1} \mathrm{H}$ - and ${ }^{13} \mathrm{C}-\mathrm{NMR}$ data $\left(\mathrm{CD}_{3} \mathrm{OD}, 500\right.$ and $\left.125 \mathrm{MHz}\right)$ of compounds 5 and $\mathbf{6 .}$

5

\begin{tabular}{|c|c|c|c|c|c|}
\hline Position & $\delta_{\mathrm{H}}$ & $\delta_{\mathrm{C}}$ & Position & $\delta_{\mathrm{H}}$ & $\delta_{\mathrm{C}}$ \\
\hline 1 & - & 132.7 & 1 & $3.75 \mathrm{~d}(J=5.1 \mathrm{~Hz})$ & 61.7 \\
\hline 2 & $7.02 \mathrm{br} \mathrm{s}(J=1.6 \mathrm{~Hz})$ & 118.6 & 2 & $4.15 \mathrm{q}$ & 83.0 \\
\hline 3 & - & 147.7 & 3 & $3.75 \mathrm{~d}(J=5.1 \mathrm{~Hz})$ & 61.7 \\
\hline 4 & - & 146.2 & 1 ' & - & 146.5 \\
\hline 5 & $6.77 \mathrm{~d}(J=8.1 \mathrm{~Hz})$ & 115.6 & 2 ' & - & 151.6 \\
\hline 6 & $6.87 \mathrm{dd}(J=8.1,1.6 \mathrm{~Hz})$ & 119.5 & 3, & $6.86 \mathrm{~d}(J=1.5 \mathrm{~Hz})$ & 113.8 \\
\hline 7 & $4.88 \mathrm{~d}(J=4.7 \mathrm{~Hz})$ & 73.2 & $4^{\prime}$ & - & 138.1 \\
\hline 8 & $\begin{array}{c}4.20 \mathrm{ddd}(J=4.7,3.8,3.0 \\
\mathrm{Hz})\end{array}$ & 87.0 & 5 & $6.74 \mathrm{dd}(J=8.1,1.5 \mathrm{~Hz})$ & 121.6 \\
\hline 9 & $\begin{array}{l}3.72 \mathrm{dd}(J=12.1,3.0 \mathrm{~Hz}) \\
3.47 \mathrm{dd}(J=12.1,3.8 \mathrm{~Hz})\end{array}$ & 60.7 & 6 ' & $6.99 \mathrm{~d}(J=8.1 \mathrm{~Hz})$ & 119.2 \\
\hline 1 ' & - & 137.2 & 7 & $2.62 \mathrm{t}(J=8.1 \mathrm{~Hz})$ & 32.4 \\
\hline 2 & $6.87 \mathrm{~d}(J=1.7 \mathrm{~Hz})$ & 112.8 & 8 & $1.82 \mathrm{~m}$ & 35.3 \\
\hline $3^{\prime}$ & - & 150.5 & 9' & $3.56 \mathrm{t}(\mathrm{J}=6.6 \mathrm{~Hz})$ & 61.9 \\
\hline 4 ' & - & 146.4 & $-\mathrm{OCH}_{3}$ & $3.84 \mathrm{~s}$ & 56.1 \\
\hline 5 & $6.98 \mathrm{~d}(J=8.1 \mathrm{~Hz})$ & 110.5 & & & \\
\hline 6 ' & $6.73 \mathrm{dd}(J=8.1,1.7 \mathrm{~Hz})$ & 120.9 & & & \\
\hline 7 & $2.63 \mathrm{t}(J=8.0 \mathrm{~Hz})$ & 31.8 & & & \\
\hline 8 & $1.82 \mathrm{~m}$ & 34.6 & & & \\
\hline 9' & $3.55 \mathrm{t}(J=6.4 \mathrm{~Hz})$ & 61.0 & & & \\
\hline$-\mathrm{OCH}_{3}$ in 3 & $3.83 \mathrm{~s}$ & 55.1 & & & \\
\hline$-\mathrm{OCH}_{3}$ in 3 ' & $3.85 \mathrm{~s}$ & 55.3 & & & \\
\hline
\end{tabular}

Two methoxyl groups ( $\delta 3.83$ and $\delta 3.85$ ) and a C-3 chain were also detected in the ${ }^{1} \mathrm{H}-\mathrm{NMR}$ spectrum. An HSQC experiment allowed the assignment of protons to the corresponding carbons while the connectivity networks through the moiety, were detected by an HMBC experiment. The most important HMBC correlation peaks were observed between H-6' $(\delta 6.73)$ and C-7' (31.8 ppm), H-8 and C-1 (132.7 ppm), H-6 ( $\delta$ 6.87) and C-7 (73.2 ppm). Further information was obtained by a ROESY experiment, which showed dipolar correlations between $-\mathrm{OCH}_{3}(\delta 3.83)$ and $\mathrm{H}-2(\delta 7.02)$ and $-\mathrm{OCH}_{3}(\delta 3.85)$ and $\mathrm{H}_{2}-7$ ' $(\delta 2.63)$. Therefore the structure of 5 was proposed as 1-(4-hydroxy-3methoxyphenyl)-2-[4-(3-hydroxypropyl)-2-methoxyphenoxy]-propane-1,3-diol, also known with the trivial name erythro-guaiacyl-glycerol- $\beta-O-4$ '-dihydroconiferyl ether. In the literature, this compound has only been previously reported following isolation from Pinus silvestris [22].

The molecular formula of compound 6 was deduced as $\mathrm{C}_{13} \mathrm{H}_{20} \mathrm{O}_{5}$ from EI-MS, which showed a $[\mathrm{M}]^{+}$peak at $m / z$ 256. The ${ }^{1} \mathrm{H}-\mathrm{NMR}$ (Table 1) and ${ }^{1} \mathrm{H}-{ }^{1} \mathrm{H}$ COSY spectra showed two one-proton doublets at $\delta_{\mathrm{H}} 6.99(\mathrm{~J}=8.1 \mathrm{~Hz})$ and $\delta_{\mathrm{H}} 6.86(\mathrm{~J}=1.5 \mathrm{~Hz})$ and a one-proton double doublet at $\delta_{\mathrm{H}} 6.74$ $(J=8.1,1.5 \mathrm{~Hz})$, suggesting a typical 1,2,4-trisubstituted aromatic ring. These spectra also included a singlet at $\delta 3.84$, ascribable to a methoxyl function, a sequence of three methylene groups $(\delta 2.62$, 
$\delta 1.82$ and $\delta 3.56)$, indicating a propanol side chain and a quintuplet at $\delta 4.15(\mathrm{H}-2)$ coupled with four protons resonating at $\delta 3.75\left(\mathrm{H}_{2}-1\right.$ and $\left.\mathrm{H}_{2}-3\right)$. The structure of 6 and the complete assignment of its ${ }^{1} \mathrm{H}$ and ${ }^{13} \mathrm{C}-\mathrm{NMR}$ data was accomplished by HSQC and HMBC experiments. The key correlations in the $\mathrm{HMBC}$ allowed the arrangement of the three substituent groups on the aromatic ring. The correlation between H-2 ( $\delta 4.15)$ and C-1' (146.5 ppm) revealed that the glycerol moiety was linked to C-1'; the correlation of H-3' $(\delta 6.86)$ and C-2' (151.6 ppm) showed a 2-OMe position; the correlation of H-3' ( $\delta$ 6.86) with C-7' (32.4 ppm) established the location of propanol side chain in C-4'. Most relevant ROESY connectivity were observed between $-\mathrm{OCH}_{3}(\delta 3.84)$ and $\mathrm{H}-3$ ' and $\mathrm{H}_{2}-1$ ( $\left.\delta 3.75\right)$ with H-6' $(\delta 6.99)$. Thus the structure of 6 was defined as 2-[4-(3-hydroxypropyl)-2-methoxyphenoxy]-propane1,3-diol. This compound was previously identified in wine from Vitis vinifera and has been described as the corresponding peracetylated derivative [23].

Several clerodane diterpenoids have been identified in previous phytochemical studies [18], but until now, floribundic acid glucoside (14) had never been detected in any species of the genus Croton.

\section{Antioxidant activity.}

All crude extracts ( $n$-hexane, $\mathrm{CHCl}_{3}, n$-BuOH and aqueous residue) obtained from the $C$. lechleri latex were analyzed for their phenolic content. The highest concentration of phenols $(306 \mathrm{mg} / \mathrm{g})$ was found in the $n-\mathrm{BuOH}$ extract and the lowest one in the $n$-hexane extract $(4.84 \mathrm{mg} / \mathrm{g})$. Consequently, the latter was not further investigated. The $\mathrm{CHCl}_{3}, n-\mathrm{BuOH}$ and aqueous residues were tested to evaluate their antioxidant potential (Table 2).

Table 2. Phenolic content and antioxidant activity of extracts, fractions, and pure compounds isolated from $C$. lechleri latex.

\begin{tabular}{|c|c|c|c|c|}
\hline \multirow[t]{2}{*}{ Sample } & \multirow{2}{*}{$\begin{array}{c}\text { Phenols } \\
\text { (mg/g extract) }\end{array}$} & \multicolumn{2}{|c|}{$\begin{array}{c}\text { Antioxidant capacity } \\
\text { (mEq uric acid) }\end{array}$} & \multirow{2}{*}{$\begin{array}{c}\text { DPPH }\left(\mathbf{I C}_{50}\right) \\
\mu \mathrm{M}\end{array}$} \\
\hline & & $1 \mu \mathbf{M}$ & $10 \mu \mathbf{M}$ & \\
\hline Ascorbic acid & n.a & $0.36 \pm 0.02$ & $0.33 \pm 0.02$ & $9.65 \mu \mathrm{M}$ \\
\hline Trolox $^{\circledR}$ & n.a & $0.85 \pm 0.07$ & $1.77 \pm 0.18$ & $12.9 \mu \mathrm{M}$ \\
\hline Quercetin & n.a & $0.75 \pm 0.06$ & $2.17 \pm 0.17$ & $4.37 \mu \mathrm{M}$ \\
\hline$n$-Hexane extract & 4.84 & 1 & 1 & 1 \\
\hline $\mathrm{CHCl}_{3}$ extract & 41.87 & $0.09 \pm 0.01$ & $0.15 \pm 0.01$ & $0.09 \mu \mathrm{M}$ \\
\hline$n$-BuOH extract & 306.01 & $0.10 \pm 0.01$ & $0.65 \pm 0.05$ & $0.875 \mu \mathrm{M}$ \\
\hline $\mathrm{H}_{2} \mathrm{O}$ residue extract & 34.37 & $0.05 \pm 0.01$ & $0.12 \pm 0.01$ & $12.4 \mu \mathrm{M}$ \\
\hline Fraction 1 & 212.90 & $0.01 \pm 0.01$ & $0.83 \pm 0.07$ & $13.1 \mu \mathrm{M}$ \\
\hline Fraction 2 & 314.55 & $0.02 \pm 0.01$ & $1.81 \pm 0.14$ & $6.10 \mu \mathrm{M}$ \\
\hline Fraction 3 & 546.47 & $0.01 \pm 0.01$ & $1.11 \pm 0.08$ & $10.9 \mu \mathrm{M}$ \\
\hline Fraction 4 & 330.51 & $0.03 \pm 0.01$ & $0.66 \pm 0.05$ & $1.41 \mu \mathrm{M}$ \\
\hline Gallocatechin & n.a & $0.16 \pm 0.03$ & $1.35 \pm 0.10$ & $10.0 \mu \mathrm{M}$ \\
\hline Epigallocatechin & n.a & $0.39 \pm 0.05$ & $2.05 \pm 0.11$ & $0.561 \mu \mathrm{M}$ \\
\hline Epicatechin & n.a & $0.09 \pm 0.01$ & $0.36 \pm 0.03$ & $19.3 \mu \mathrm{M}$ \\
\hline
\end{tabular}

Experiments were performed in triplicate; results are mean $\pm \mathrm{SD}$. 
As expected, the $n$-BuOH extract showed the highest activity; in particular it exhibited a scavenging action toward the stable radical DPPH which was stronger than that of all three reference compounds, i.e. quercetin, Trolox ${ }^{\circledR}$, and ascorbic acid. Only the $\operatorname{Sephadex}^{\circledR}$ fractions $(1,2,3$ and 4) obtained from this extract were examined for their antioxidant activity (Table 2). The scavenging abilities of the four fractions were comparable with those of the standards; the overall antioxidant capacity yielded similar results, but only at $10 \mu \mathrm{M}$ concentrations. In both tests, fractions 2 and 3 showed the strongest activity. From these fractions, epigallocatechin and gallocatechin were isolated and then investigated. Two pure compounds exhibited remarkable antioxidant activities (Table 2) both in terms of DPPH removal (with values lower than those of quercetin and Trolox ${ }^{\circledR}$ ) and of antioxidant capacity (with results similar to those of the quercetin and Trolox ${ }^{\circledR}$ ). Epicatechin was isolated from fraction 4 ; the activity of this molecule ( $\mathrm{IC}_{50}: 19.3 \mu \mathrm{M}$; Table 2 ) was in line with that reported in the literature [3]. The presence of epicatechin and catechin in only trace amounts in the $\mathrm{CHCl}_{3}$ extracts explains their lack of antioxidant activity.

\section{Conclusions}

In summary, we have revealed for the first time the presence in C. lechleri latex, of minor secondary metabolites as megastigmane, lignan, and clerodane derivatives. The results obtained by testing the $n-\mathrm{BuOH}$ extract may be ascribable to flavan-3-ols, that are the strongest antioxidants among latex phenols. The complexity of the chemical profile suggested that the role of each individual compound in the latex is important in the interpretation of the pharmacological effects exhibited by sangre de drago, which deserve further investigations.

\section{Experimental}

\section{General}

${ }^{1} \mathrm{H}$ - and ${ }^{13} \mathrm{C}$-NMR spectra were determined at 500.13 and $125.77 \mathrm{MHz}$, respectively, on a Varian Unity INOVA spectrometer equipped with an indirect detection probe. Chemical shifts were referenced to the solvent signals of deuterated methanol $\left(\mathrm{CD}_{3} \mathrm{OD}\right)$, residual $\mathrm{CHD}_{2} \mathrm{OD}: \delta_{\mathrm{H}} 3.31, \delta_{\mathrm{C}}$ 49.0. Electron ionization mass spectrometry (EI-MS) and ESI-MS were recorded on a Fisons VG Prospec instrument. Droplet counter-current chromatography (DCCC) was performed on a DCC-A apparatus (Tokyo Rikakikai Co., Tokyo-Japan) equipped with 250 glass-columns. HPLC was performed using a Waters 510 pump equipped with a Waters U6K injector and a Waters 401 differential refractometer as detector, using a $30 \mathrm{~cm}$ x $3.9 \mathrm{~mm}$; i.d., $\mathrm{C}_{18} \mu$-Bondapak (Waters, Milford, MA, USA) columns; flow rate was $1 \mathrm{mLmin}^{-1}$. The secondary metabolites were identified by a combination of spectroscopic methods $\left({ }^{1} \mathrm{H},{ }^{13} \mathrm{C}\right.$ NMR and 2D-NMR experiments), ESI-MS and comparison with the literature data. 


\section{Plant Material}

The sap of C. lechleri (Euphorbiaceae) was collected in 2006 from the tropical region of Upper Huallaga Valley (Tingo Maria, Peru) and kept at $4{ }^{\circ} \mathrm{C}$ in the dark. A $100 \mathrm{~mL}$ sample of the reddish latex is deposited ( $\mathrm{N}^{\circ} \mathrm{SD}-518$ ) in the herbarium of the University of Molise (Pesche, Isernia, Italy).

\section{Extraction and Isolation}

A small portion $(150 \mathrm{~mL})$ of sap was dissolved in $\mathrm{MeOH}-\mathrm{H}_{2} \mathrm{O}(9: 1, \mathrm{v} / \mathrm{v}, 200 \mathrm{~mL})$ and extracted with $n$-hexane ( $3 \times 150 \mathrm{~mL})$, following Kupckan's partitioning method [27]. The water content (\% v/v) of the $\mathrm{MeOH}$ was adjusted to $40 \%$ and the resulting solution was partitioned against $\mathrm{CHCl}_{3}$. The $\mathrm{MeOH}$ was removed from the aqueous phase, which was then extracted with $n$-BuOH. This gave three extracts: $n$-hexane (80.3 mg), $\mathrm{CHCl}_{3}(1.2 \mathrm{~g}), n-\mathrm{BuOH}(3.6 \mathrm{~g})$ and an aqueous residue (7.8 g). The $n$ $\mathrm{BuOH}$ residue was chromatographed on Sephadex ${ }^{\circledR}$ LH-20 (MeOH eluent). Fractions were collected and combined according to TLC analysis into four main fractions. Fraction 1 was submitted to DCCC with $n$ - $\mathrm{BuOH}-\mathrm{Me}_{2} \mathrm{CO}-\mathrm{H}_{2} \mathrm{O}(3: 1: 5)$ in the descending mode (the upper phase was the stationary phase), to give four main fractions, which were analyzed by silica gel TLC $\left[n-\mathrm{BuOH}-\mathrm{HOAc}-\mathrm{H}_{2} \mathrm{O}(12: 3: 5)\right.$ and $\mathrm{CHCl}_{3}-\mathrm{MeOH}-\mathrm{H}_{2} \mathrm{O}(80: 18: 2)$ as eluents] and purified by HPLC with $\mathrm{MeOH}-\mathrm{H}_{2} \mathrm{O}(15: 85)$ as the mobile phase. Fractions 2, 3, and 4 contained mainly 7 (5.2 $\mathrm{mg}), \mathbf{1 0}(11,8 \mathrm{mg})$ and 9 (3.0 $\mathrm{mg})$, respectively. The $\mathrm{CHCl}_{3}$ extract was chromatographed by DCCC using $\mathrm{CHCl}_{3}-\mathrm{MeOH}-\mathrm{H}_{2} \mathrm{O}(7: 13: 8)$ in ascending mode (the lower phase was the stationary phase). Six fractions (A-F) were obtained and purified by HPLC as follows. Fraction A was purified with $\mathrm{MeOH}-\mathrm{H}_{2} \mathrm{O}(1: 9)$ and contained 7 (2.9 mg) and 8 (4 mg); fraction $\mathrm{B}$, eluted with $\mathrm{MeOH}-\mathrm{H}_{2} \mathrm{O}(15: 85)$, contained 6 (1.6 mg); fraction $\mathrm{C}$ contained mainly $14\left(1.2 \mathrm{mg}\right.$ ) and was eluted with $\mathrm{MeOH}-\mathrm{H}_{2} \mathrm{O}(4: 6)$; fraction $\mathrm{D}$, eluted with $\mathrm{MeOH}-\mathrm{H}_{2} \mathrm{O}(2: 8)$, contained 3 (9.5 mg), 2 (2.2 mg), 12 (0.8 mg), and 5 (1.3 mg); Compounds 4 (3.9 mg), 11 (2.8 mg) and $13(1.7 \mathrm{mg})$ were obtained from fraction $\mathrm{E}$, eluted with $\mathrm{MeOH}-\mathrm{H}_{2} \mathrm{O}(25: 75)$; fraction $\mathrm{F}$, eluted with $\mathrm{MeOH}-\mathrm{H}_{2} \mathrm{O}(3: 7)$, contained mainly $1(8.6 \mathrm{mg})$.

\section{Isolation and identification of alkaloids}

C. lechleri latex $(50 \mathrm{~mL})$ was lyophilized to yield $7.6 \mathrm{~g}$ of reddish-powdered latex. A portion (3.0 g) of the powdered latex was combined with distilled $\mathrm{H}_{2} \mathrm{O}(150 \mathrm{~mL})$ and acidified with concentrated $\mathrm{HCl}$. The aqueous layer was continuously extracted with $\mathrm{CHCl}_{3}$ for $12 \mathrm{~h}$ and its $\mathrm{pH}$ was then adjusted to 8 with concentrated $\mathrm{NH}_{4} \mathrm{OH}$. This fraction was then continuously extracted with $\mathrm{CHCl}_{3}$ over $12 \mathrm{~h}$ to yield the first basic fraction. Following adjustment of $\mathrm{pH}$ to 10 with $\mathrm{NH}_{4} \mathrm{OH}$, the aqueous layer was extracted for an additional $12 \mathrm{~h}$ with $\mathrm{CHCl}_{3}$ to yield the second basic fraction. TLC examination of the two basic fractions with Dragendorff's reagent showed reagent-positive component in the second basic fraction. This fraction was dissolved in $\mathrm{MeOH}$ with warming, and $\mathbf{1 5}(11.3 \mathrm{mg})$ was obtained as a white precipitate upon refrigeration.

EI-MS data: Blumenol B (1): m/z 224 [M] $]^{+}\left(\mathrm{C}_{13} \mathrm{H}_{20} \mathrm{O}_{3}\right)$; Blumenol C (2): m/z 208 [M] $]^{+}\left(\mathrm{C}_{13} \mathrm{H}_{20} \mathrm{O}_{2}\right)$; 4,5Dihydroblumenol A (3): m/z $226\left[\mathrm{M}^{+}\left(\mathrm{C}_{13} \mathrm{H}_{22} \mathrm{O}_{3}\right) ; 3\right.$ ',4-O-Dimethylcedrusin (4): $\mathrm{m} / \mathrm{z} 374[\mathrm{M}]^{+}$ 
$\left(\mathrm{C}_{21} \mathrm{H}_{26} \mathrm{O}_{6}\right)$; (-)-Epicatechin (7): m/z $290[\mathrm{M}]^{+}\left(\mathrm{C}_{15} \mathrm{H}_{14} \mathrm{O}_{6}\right)$; (+)-Catechin (8): m/z $290[\mathrm{M}]^{+}\left(\mathrm{C}_{15} \mathrm{H}_{14} \mathrm{O}_{6}\right)$; (-)-Epigallocatechin (9): m/z $306[\mathrm{M}]^{+}\left(\mathrm{C}_{15} \mathrm{H}_{14} \mathrm{O}_{7}\right)$; (+)-Gallocatechin (10): m/z $306[\mathrm{M}]^{+}\left(\mathrm{C}_{15} \mathrm{H}_{14} \mathrm{O}_{7}\right)$; Compound 11: m/z $224[\mathrm{M}]^{+}\left(\mathrm{C}_{12} \mathrm{H}_{16} \mathrm{O}_{4}\right)$; Compound 12: m/z $196[\mathrm{M}]^{+}\left(\mathrm{C}_{11} \mathrm{H}_{16} \mathrm{O}_{3}\right)$; Compound 13: $\mathrm{m} / \mathrm{z}$ $226[\mathrm{M}]^{+}\left(\mathrm{C}_{12} \mathrm{H}_{18} \mathrm{O}_{4}\right)$; Floribundic acid glucoside (14): $\mathrm{m} / \mathrm{z} 529[\mathrm{M}+\mathrm{Na}]^{+}\left(\mathrm{C}_{26} \mathrm{H}_{34} \mathrm{O}_{10}\right)$; Taspine (15): $\mathrm{m} / \mathrm{z} 369[\mathrm{M}]^{+}\left(\mathrm{C}_{20} \mathrm{H}_{19} \mathrm{NO}_{6}\right)$.

( \pm ) erythro-Guaiacyl-glycerol- $\beta$-O-4'-dihydroconiferyl ether (5): $[\alpha]_{D}^{25}=0^{\circ}(\mathrm{MeOH}, \mathrm{c} 0.09)$; EI-MS $\mathrm{m} / \mathrm{z} 378[\mathrm{M}]^{+}\left(\mathrm{C}_{20} \mathrm{H}_{26} \mathrm{O}_{7}\right) ;{ }^{1} \mathrm{H}$ - and ${ }^{13} \mathrm{C}$-NMR see Table 1.

2-[4-(3-Hydroxypropyl)-2-methoxyphenoxy]-propane-1,3-diol (6): EI-MS m/z $256[\mathrm{M}]^{+}\left(\mathrm{C}_{13} \mathrm{H}_{20} \mathrm{O}_{5}\right)$; ${ }^{1} \mathrm{H}$ - and ${ }^{13} \mathrm{C}$-NMR see Table 1.

Determination of phenolic content

Total phenols of the extracts and fractions were quantified by the Folin-Ciocalteau spectrophotometric assay, using gallic acid as the reference standard [28]. Therefore, molarity refers is expressed as gallic acid equivalents.

\section{Total antioxidant capacity}

The total antioxidant capacity of the samples at concentrations of 10 and $1 \mu \mathrm{M}$ was determined by a validated method based upon the copper reduction $\left(\mathrm{Cu}^{2+}\right.$ to $\left.\mathrm{Cu}^{+}\right)$. $\left(\mathrm{BIOXYTECH}^{\circledR}\right.$ AOP-490TM, Oxis Research $^{\mathrm{TM}}$, Portland, OR) [29]. The reference compound was uric acid and then results are expressed as $\mathrm{mEq}$ uric acid.

\section{DPPH scavenging test}

Suitable aliquots of a methanolic solution containing each sample, at increasing concentrations from $1 \mu \mathrm{M}$ to $100 \mu \mathrm{M}$, were added to $15 \mu \mathrm{M}$ ethanol solution of 2,2-diphenyl-2-picrylhydrazyl radical (DPPH). Absorbance was read at $517 \mathrm{~nm}$ after $15 \mathrm{~min}$ of incubation in the dark [30]. The $\mathrm{IC}_{50}$ was calculated by employing Prism ${ }^{\circledR} 4$ (GraphPad Software Inc.).

\section{Acknowledgements}

MS and NMR spectra were provided by the Centro di Servizio Interdipartimentale di Analisi Strumentale (CSIAS), Università di Napoli “Federico II", Napoli, Italy.

\section{References}

1. Milanowsky, D.J.; Winter, R.E.; Elvin-Lewis, M.P.; Lewis, W.H. Geographic distribution of the alkaloid chemotypes of Croton lechleri. J. Nat. Prod. 2002, 65, 814-819. 
2. Desmarchelier, C.; Witting Schaus, F.; Coussio, J.; Cicca, G. Effects of Sangre de Drago from Croton lechleri Muell.-Arg. on the production of active oxygen radicals. J. Ethnopharmacol. 1997, 58, 103-108.

3. Risco, E.; Ghia, F.; Vila, R.; Iglesias, J.; Alvarez, E.; Canigueral, S. Immunomodulatory activity and chemical characterisation of sangre de drago (dragon's blood) from Croton lechleri. Planta Med. 2003, 69, 785-794.

4. Ubillas, R.; Jolad, S.D.; Bruening, R.C.; Kernan, M.R.; King, S.R.; Sesin, D.F.; Barrett, M.; Stoddart, C. A.; Flaster T. SP-303, an antiviral oligomeric proanthocyanidin from the latex of Croton lechleri (Sangre de Drago). Phytomedicine 1994, 1, 77-106.

5. Pieters, L.; de Bruyne, T.; Claeys, M.; Vlietinck, A.; Calomme, M.; Vanden Berghe, D. Isolation of a dihydrobenzofuran lignan from South American Dragon's Blood (Croton spp.) as an inhibitor of cell proliferation. J. Nat. Prod. 1993, 56, 899-906.

6. Carlson, T.J.S.; King, S.R. Sangre de drago (Croton lechleri Mell-Arg) a phytomedicine for the treatment of diarrhoea. Health Notes. Rev. Compl. Integr. Med. 2000, 7, 315-320.

7. Di Cesare, D.; Du Pont, H.L.; Mathewson, J.J.; Ashley, D.; Martinez-Sandoval, F. ; Pennington, J.E. ; Porter, S.BA double blind, randomized placebo-controlled study of SP-303 (Provir) in the symptomatic treatment of acute diarrhoea among travellers to Jamaica and Mexico. Am. J. Gastroent. 2002, 97, 2585-2588.

8. Holodniy, M.; Koch, J.; Mistal, M.; Schmidt, J.M.; Khandwala, A.; Pennington, J.E. Porter, S.B. A double blind, randomized placebo-controlled phase II study to assess the safety and efficacy of orally administered SP-303 for symptomatic treatment of diarrhoea in patients with AIS. Am. J. Gastroent. 1999, 94, 3267-3273.

9. Fisher, H.; Machen, T.E.; Widdicombe J.H.; Carlson, T.J.S.; King, S.R.; Chow, J.W.S.; Illek, B. A novel extract SB-300 from the steam bark latex of Croton lechleri inhibits CFTR-mediated chloride secretion in human colonic epithelial cells. 2004, J Ethnopharmacol. 2004, 351-357.

10. Jones, K. Review of Sangre de drago (Croton lechleri) a south American tree sap in the treatment of diarrhea, inflammation, insect bites, viral infections and wounds: traditional uses to clinical research. J. Altern. Complement. Med. 2003, 9, 877-896.

11. Vaisberg, A.J.; Milla M.; del Carmen Planas, M.; Cordova, J.L.; Rosas de Agusti, E.; Ferreyra, R.; del Carmen Mustiga, M.; Carlin, L.; Hammond, G.B. Taspine is the cicatrizant principle in Sangre de Grado extracted from Croton lechleri. Planta Med. 1989, 55, 140-143.

12. Phillipson, J. D. Review. A matter of some sensitivity. Phytochemistry 1995, 38, 1319-1343.

13. Hartwell, J.L. Plants used against cancer : a survey. Lloydia 1969, 32, 158-176.

14. Bettolo, R.M.; Scarpati, M.L. Alkaloids of Croton draconoides. Phytochemistry 1979, 18, 520.

15. Chen, Z. P.; Cai, Y.; Phillipson, J.D. Studies on the anti-tumour, anti-bacterial, and woundhealing properties of Dragon's Blood. Planta Med. 1994, 60, 541-5.

16. Lopes e Lopes, M.I.; Saffi, J.; Echeverrigaray S,; Pegas Henriques, J.A.; Salvador, M. Mutagenic and antioxidant activities of Croton lechleri sap in biological systems. J. Ethopharmacol. 2004, 95, 437-445.

17. Cai, Y.; Evans, F.J.; Roberts, M.F.; Phillipson, J.D.; Zenk, M.H.; Gleba, Y.Y. Biological and chemical investigation of Dragon's Blood from Croton species of South America. Part 1. Polyphenolic compounds from Croton lechleri. Phytochemistry 1991, 30, 2033-2040. 
18. Cai, Y.; Chen, Z.P.; Phillipson, J.D. Biological and chemical investigation of Dragon's Blood from Croton species of South America. Part 3. Clerodane diterpenoids from Croton lechleri. Phytochemistry 1993, 34, 265-268.

19. Cai, Y.; Chen, Z.P.; Phillipson, J.D. Biological and chemical investigation of Dragon's Blood from Croton species of South America. Part 2. Diterpenes from Croton lechleri. Phytochemistry 1993, 32, 755-760.

20. Galbraith, M.N.; Horn, D.H.S. Structures of the natural products blumenols A, B, and C. J. Chem. Soc. Chem. Comm. 1972, 3, 113-114.

21. De Marino, S.; Borbone, N.; Zollo, F.; Ianaro, A.; Di Meglio, P.; Iorizzi, M. Megastigmane and phenolic components from Laurus nobilis L. leaves and their inhibitory effects on nitric oxide production. J. Agric. Food Chem. 2004, 52, 7525-7531.

22. Sinkkonen, J.; Karonen, M.; Liimatainen, J.; Pihlaja, K. Lignans from the bark extract of Pinus sylvestris L. Magn. Res. Chem. 2006, 44, 633-636.

23. Baltenweck-Guyot, R.; Trendel, J.M.; Albrecht, P.; Schaeffer, A. Glycosides and phenylpropanoid glycerol in Vitis vinifera cv. Gewurztraminer wine. J. Agric. Food Chem. 2000, 48, 6178-6182.

24. Achenbach, H.; Hemrich, H. Constituents of tropical medicinal plants. Part 40. Alkaloids, flavonoids and phenylpropanoids of the West African plant Oxymitra velutina. Phytochemistry 1991, 30, 1957-1962.

25. Arnoldi, A.; Merlini, L. Asymmetric synthesis of 3-Methyl-2-phenyl-1,4-benzodioxanes. Absolute configuration of the neolignans eusiderin and eusiderin C and D. J. Chem. Soc. Perkin Trans. I, 1985, 2555-2557

26. Fang, J.; Lee, C.; Cheng, Y. Lignans from leaves of Juniperus chinensis. Phytochemistry 1992, 31, 3659-3661.

27. Kupchan, S.M.; Britton, R.W.; Ziegler, M.F.; Sigel, C. W. Bruceantin, a new potent antileukemic simaroubolide from Brucea antidysenterica. J. Org. Chem. 1973, 38, 178-179.

28. Visioli, F.; Vinceri, F.F.; Galli, C. 'Waste water' from olive oil production are rich in natural antioxidants. Experientia 1995, 51, 32-34.

29. Visioli, F.; Caruso, D.; Plasmati, E.; Patelli, R.; Mulinacci, N.; Romani, A.; Galli, G.; Galli, C. Hydroxytyrosol, as a component of olive mill waste water, is dose-dependently absorbed and increases the antioxidant capacity of rat plasma. Free Radical Res. 2001, 34, 301-305.

30. Visioli, F.; Galli, C. The effect of minor constituents of olive oil on cardiovascular disease: new findings. Nutrition Rev. 1998, 56, 142-147.

Sample Availability: Contact the authors

(C) 2008 by the authors; licensee Molecular Diversity Preservation International, Basel, Switzerland. This article is an open-access article distributed under the terms and conditions of the Creative Commons Attribution license (http://creativecommons.org/licenses/by/3.0/). 